\title{
Approccio algoritmico per l'applicazione degli standard grafici in ambiente BIM
}

\author{
Matteo Del Giudice \\ Emmanuele lacono
}

\section{Abstract}

L'innovazione tecnologica sta attualmente cambiando l'industria delle costruzioni, influenzata dal processo di digitalizzazione della quarta rivoluzione industriale.

Similmente, ciò influenza la capacità dei domini di dati di consentire connessioni tra informazioni digitali sull'edificio e la loro rappresentazione, anche con l'uso di numerosi dispositivi loT.

Una delle innovazioni è lo sviluppo di database digitali basati sulla metodologia BIM, che permette lo scambio informativo effettuato usando strategie di rappresentazione sia tradizionali che innovative. Ciò è dovuto alle necessità dell'era della connessione, che richiede modelli basati su rete con un alto livello di maturità BIM.

Poiché la produzione di contenuti di progetto si affida ancora a standard e convenzioni tradizionali, il contributo mira a valutare la capacità dei modelli collaborativi BIM di produrre elaborati grafici 2D e 3D, secondo le fasi attuali del processo edilizio.

Considerando la differenza tra viste e disegni, lo studio fornisce un approccio analitico basato su algoritmo che ottimizzi la visualizzazione degli oggetti BIM in base alla scala di rappresentazione associata al loro livello di dettaglio grafico e alfanumerico.

Le sfide incontrate dal presente lavoro riguardano principalmente i limiti delle tecnologie attuali e il contrasto tra metodologie BIM e standard grafici, che spingono perciò gli utilizzatori a manipolare inefficentemente rappresentazioni BIM intelligenti con aggiunte manuali.

Parole chiave

Building Information Modeling;Visual Programming Language; standard grafici; BIM connesso; algoritmi.

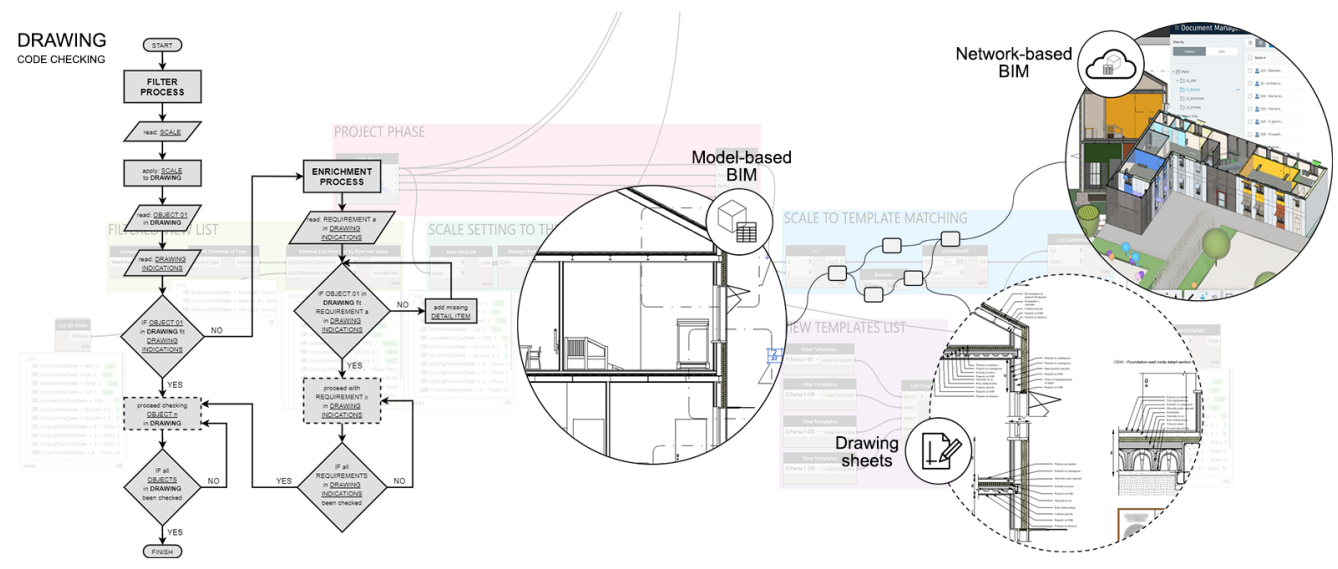




\section{Introduzione}

Negli ultimi anni, il settore delle costruzioni ha attraversato un processo di digitalizzazione influenzato dalle tecnologie dell'informazione e della comunicazione (TIC) che stanno cambiando il modo di comunicare le idee progettuali. La società contemporanea, guidata dall'innovazione tecnologica, si sta muovendo verso sistemi sempre più complessi e connessi per ottimizzare la gestione dei dati e sviluppare città e società intelligenti.

L'introduzione di sensori negli edifici consente di sviluppare modelli innovativi di edificio non solo attraverso i suoi componenti fisici, ma anche attraverso il suo comportamento dinamico. Questi modelli necessitano di interfacce grafiche che devono essere in grado di descrivere la realtà per soddisfare le esigenze degli stakeholder coinvolti.

Per questo motivo, la rappresentazione progettuale si sta dirigendo verso la metodologia BIM (Building Information Modeling), basata sull'elaborazione di un modello 3D parametrico, ricco di contenuti grafici e alfanumerici, in grado di ottimizzare la gestione informativa del processo edilizio [Osello 20I2].

I modelli informativi devono quindi essere organizzati per essere rappresentati non solo attraverso standard grafici e convenzioni, ma anche in modi innovativi come la realtà virtuale e aumentata (VAR). In questo senso, lo sviluppo di modelli in grado di rappresentare gli edifici e il loro comportamento comporta la generazione di un modello 3D parametrico collegato ai vari sensori che devono essere connessi tra loro per la generazione di un gemello digitale [Mateev 2020].

In questa era di connessione [Autodesk 2020], lo sviluppo di modelli BIM connessi dovrebbe basarsi su: I) set di dati in grado di descrivere le caratteristiche statiche e dinamiche dell'edificio; 2) algoritmi in grado di elaborare grandi quantità di dati per conoscere il presente e prevedere il futuro; 3 ) interfacce intelligenti per facilitare l'interazione uomo-macchina (fig. I). Tutto ciò dovrebbe essere possibile condividendo informazioni tra gli utenti [Ratti et al. 2017; Garzino 20I I].

Attualmente, il concetto di modello BIM collegato è spesso legato allo sviluppo di Common Data Environment (CDE), non collegati tuttavia ad algoritmi che ottimizzino la rappresentazione grafica in base ai requisiti di progettazione, non raggiungendo il livello di maturità BIM richiesto per l'Integrated Project Delivery (IPD) [Underwood et al. 2009].

In realtà questo tipo di connessione implica, nel migliore dei casi, la possibilità di utilizzare sistemi basati su cloud per la sola visualizzazione. Uno scenario migliore sarebbe quello in cui tutti gli stakeholder possano essere in grado non solo di visualizzare, ma anche di agire direttamente sul modello in avanzamento per i rispettivi settori.

Sebbene l'attuale processo BIM generi disegni di progetto significativamente migliori a seguito di uno schema integrato di modelli, strumenti analitici, Big Data e infrastrutture colla-

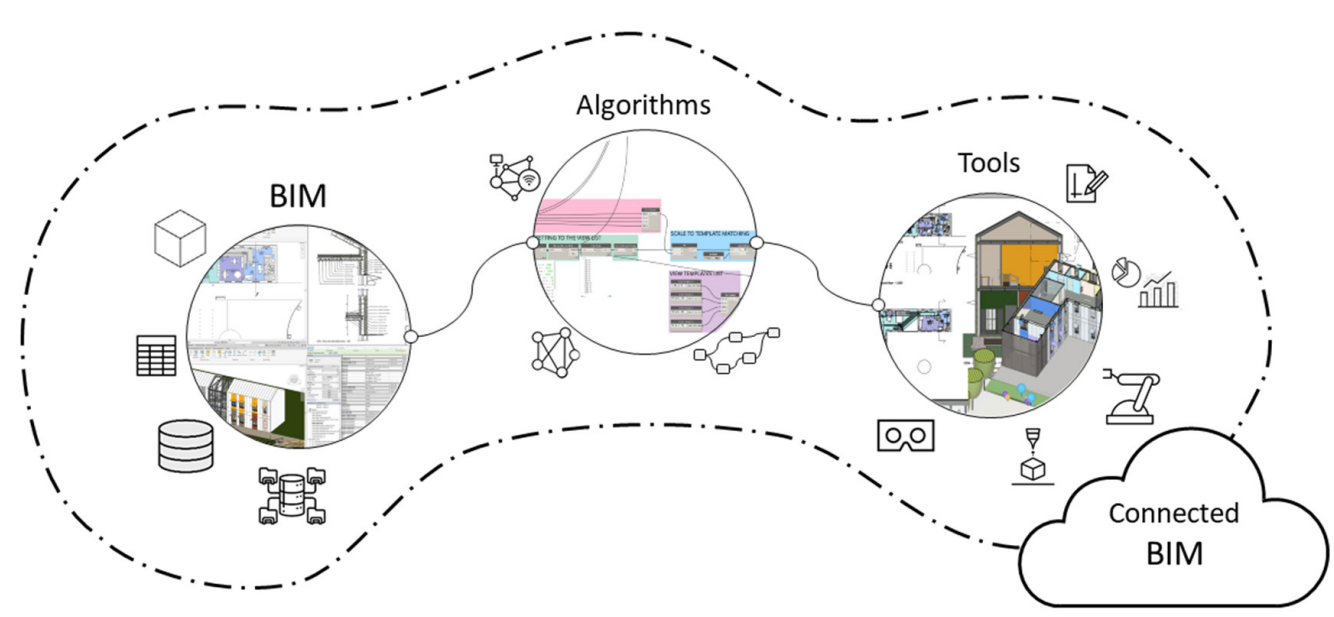


borative, attualmente esiste una deviazione tra la produzione di queste visualizzazioni e le rappresentazioni grafiche che fanno riferimento a standard e convenzioni codificate nella disciplina del disegno.

Questo documento presenta un approccio analitico basato su algoritmi finalizzato all'ottimizzazione della rappresentazione grafica del BIM. L'approccio proposto prevede l'applicazione automatica delle regole di rappresentazione applicate alle viste del modello BIM per avvicinare i contenuti forniti dalle piattaforme BIM a quelli richiesti dalle norme sul disegno, la cui analisi è stata avviata nell'ambito del corso di disegno tenuto dalla professoressa Novello presso il Politecnico diTorino.

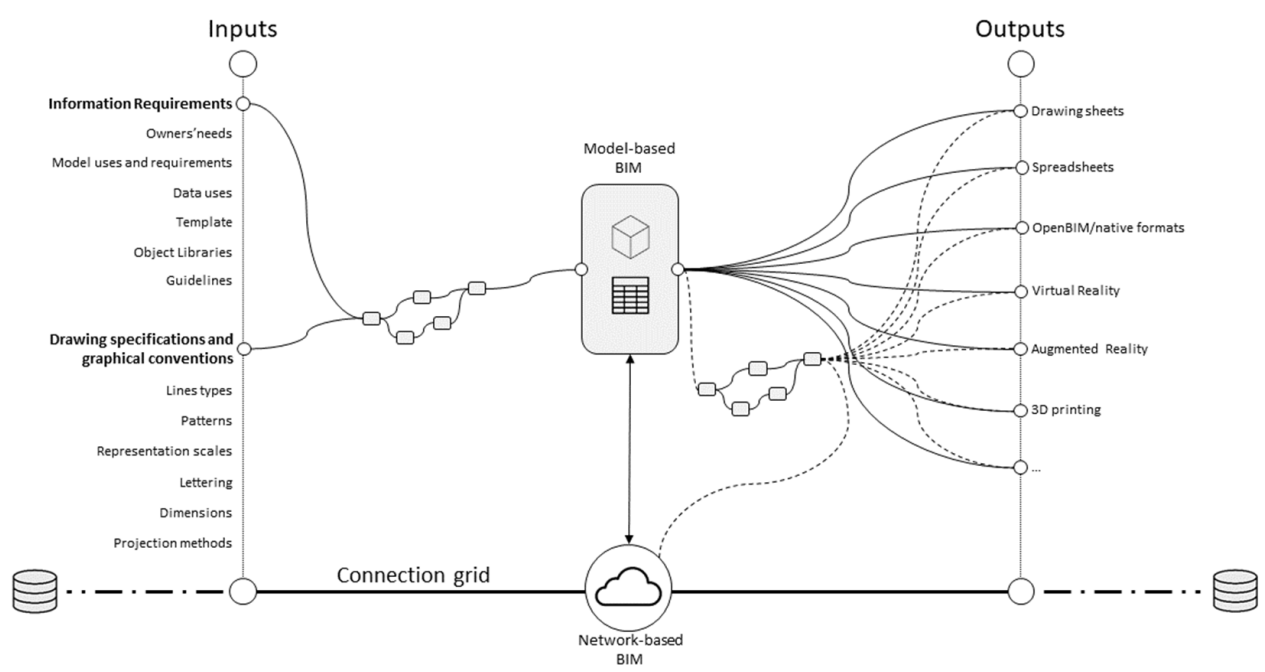

\section{Metodologia}

Ad oggi, la creazione di un modello BIM correttamente collegato si basa su tre fasi principali: I) definizione dell'input; 2) creazione di modelli 3D parametrici basati su file; 3) produzione degli output. In particolare, lo sviluppo di un modello parametrico 3D parte da requisiti informativi, specifiche sul disegno e convenzioni grafiche come input. Tali specificità devono essere manipolate per ottenere output grafici e alfanumerici in grado di migliorare la comunicazione del progetto.

Attualmente, il trattamento dei dati si basa su algoritmi strutturati ad-hoc per questo tipo di operazioni di conversione, regolati dagli utenti autorizzati per la loro impostazione in funzione di progetti, requisiti e output specifici. Attraverso tale attività, tutte le rappresentazioni del progetto vengono rese conformi agli standard adottati senza ulteriore manipolazione, con un risultante beneficio a livello grafico.

L'ottenimento di un modello BIM connesso (fig. 2) implica ad oggi il suo caricamento su una piattaforma in rete per aumentare la condivisione di informazioni. Tale connessione tra il modello su file e il modello in rete potrebbe essere regolata anche da algoritmi.

Per unificare le diverse modalità di rappresentazione del progetto, è innanzitutto fondamentale considerare sia quelle riguardanti il processo di costruzione sia quelli della metodologia BIM (fig. 3). Per quanto riguarda le prime, nel Codice degli appalti pubblici (D.Lgs. 50/20 I6) sono indicate alcune macrofasi del processo edilizio, in particolare per quanto riguarda la fase di progettazione. Le fasi prima e dopo di essa sono aggiunte per completare la sequenza del processo. Dal punto di vista della metodologia BIM, tuttavia, ci sono livelli di sviluppo (LOD), che la legislazione italiana suddivide in sette fasce, che variano l'una dall'altra per contenuti grafici e informativi [De Gregorio 20l8] [Novello et al. 2014]. Inoltre, esiste il concetto di Graphic Detail (GraDe), proposto dal AEC (UK) BIM Protocol V2.0, che tuttavia 
riguarda solo il contenuto grafico dei modelli [Caffi et al. 20 17]. Individuando una corrispondenza tra queste tre diverse espressioni dell'evoluzione del progetto, attraverso le scale di rappresentazione, è possibile tracciare un percorso logico che, a partire dalle esigenze di progettazione e i requisiti della fase corrente del processo, imposti automaticamente rappresentazioni e contenuti corretti di tale fase.

Definiti fase, scala, LOD, e requisiti di progetto, il flusso di lavoro proposto (fig. 4) mostra un algoritmo composto da una serie di matrici in grado di regolare la rappresentazione del progetto di conseguenza. Idealmente, si procede come segue: a seconda della fase del progetto in cui l'utente si trova, vi è una fase corrispondente del processo di costruzione, che sia lo studio di fattibilità, la fase di progettazione definitiva o esecutiva. Questo è un primo input nello schema logico. Un secondo è dato dal LOD, in base al livello di dettaglio da raggiungere nei vari elaborati di progetto e al rispettivo contenuto informativo. La possibilità

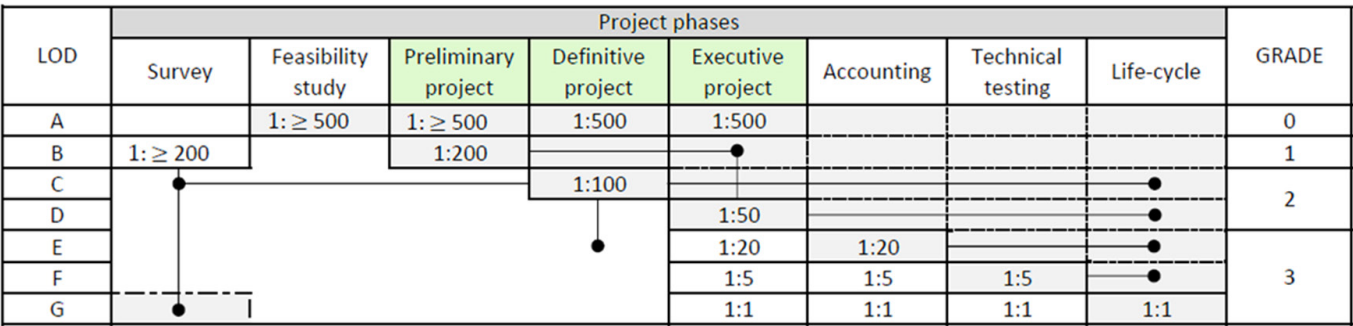

di incrociare la fase del processo edilizio con il LOD, specialmente la componente grafica, stabilisce le scale di rappresentazione corrette (1:500, 1:200, 1: I00 ecc.) per soddisfare le richieste iniziali. Dopodiché scala grafica e prodotti da consegnare sono correlati per comunicare correttamente il progetto; quest'ultima costituisce il terzo e ultimo input dell'algoritmo. II progetto, suddiviso nelle rappresentazioni richieste, incrocia le scale richieste dai primi due input, generando una prima matrice dei documenti necessari per completare la fase corrente del processo. In dettaglio, ogni elemento della matrice deve passare attraverso un cosiddetto Filter, identificato per ogni tipo di vista (ad es. piante I:200, sezioni I: I00, esecutivi I:50, dettagli I:20 ecc.). II filtro è una serie di requisiti di sistema, per i quali esistono una o più impostazioni specifiche all'interno del software in uso (tipi e spessori di linea, tratteggi, profili ecc.). L'operazione migliora la visualizzazione delle varie viste di modello secondo le convenzioni e le norme sul disegno. Un secondo step riguarda ciò che è stato identificato come Enrichment, ossia un'implementazione specifica dei contenuti e delle viste del modello. Ogni oggetto viene analizzato con operazioni che aggiungono elementi specifici a esso attraverso categorie di elementi di dettaglio e linee di dettaglio, nonché operazioni che agiscono sulle viste aggiungendo elementi di categorie di annotazione (cartigli, quote, simboli, tag o testi). Una volta terminata la fase di arricchimento, è possibile produrre disegni

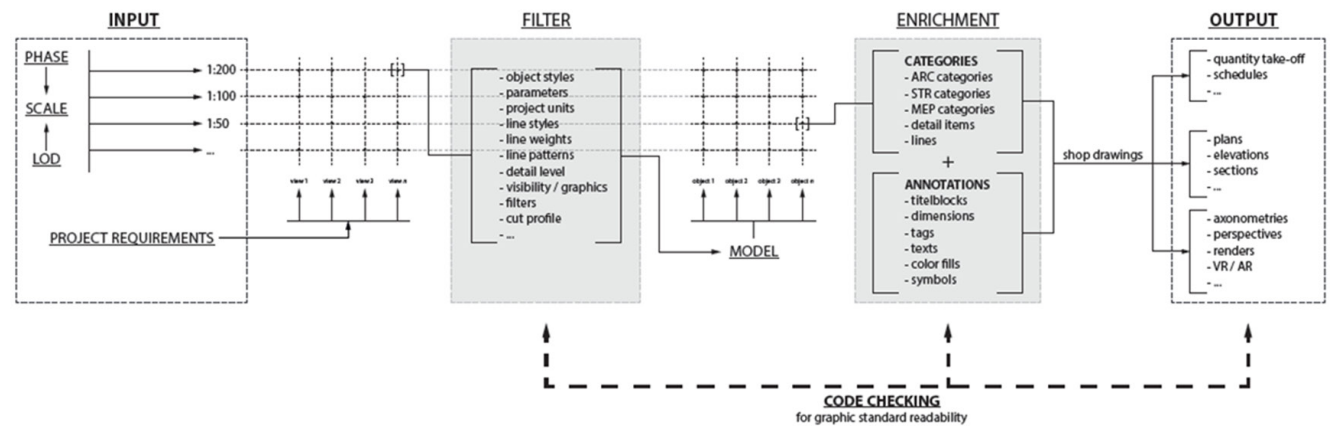


che soddisfano effettivamente i requisiti normativi, siano essi rappresentazioni 2D (piante, prospetti, sezioni, abachi ecc.) o 3D (assonometrie, prospettive, render,VR/AR ecc.). Questi costituiscono l'output finale del processo logico, sul quale è ancora possibile eseguire una validazione, fornendo un responso sulla correttezza dei filtri impostati all'interno del software. Il prodotto di questa complessa serie di operazioni è il miglioramento del Level of Geometry (LOG) e l'aggiunta di vari elementi di dettaglio che aiutano a comprendere le fasi di progetto più avanzate, così come il miglioramento del Level of Information (LOI) [Pavan et al., 20 I 7] (fig. 5). A seconda degli strumenti di BIM authoring utilizzati, questa operazione com-

\section{OBJECTS LOD}
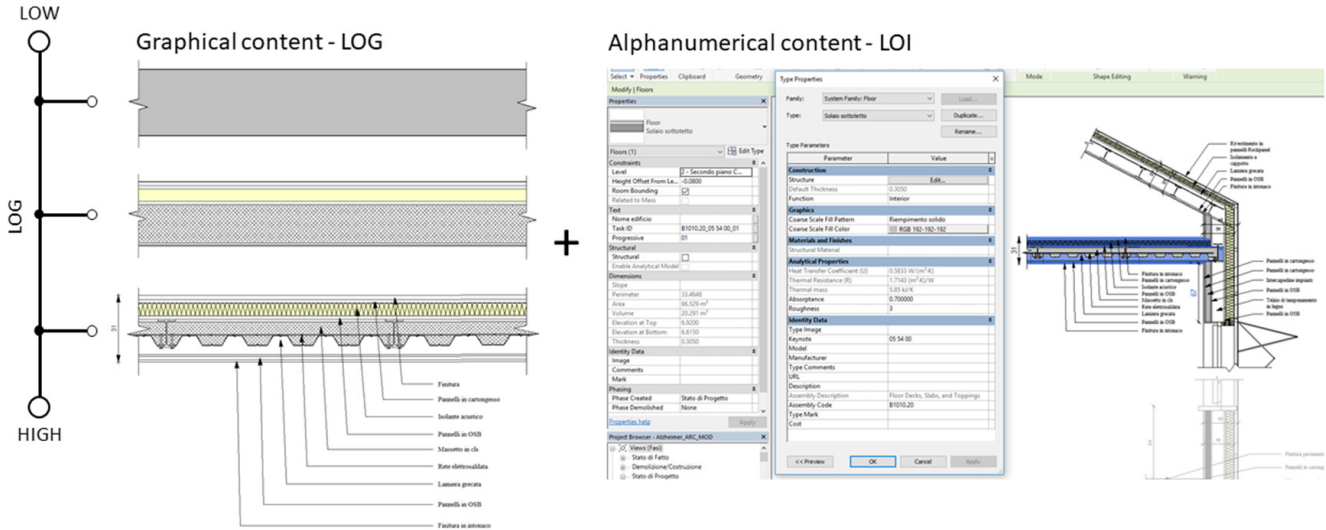

porta diversi sottoinsiemi di impostazioni di rappresentazione, basati su filtri grafici, aggiunta di componenti, annotazioni, compilazione manuale o automatica di varie proprietà dell'oggetto. Per questo studio, Autodesk Revit è stata scelto come piattaforma BIM authoring per valutare i punti di forza e debolezza del modello informativo. II livello di automazione è un punto cruciale in questo processo, poiché a seconda della sua incidenza, tale processo diventa più o meno impegnativo.

II diagramma di flusso (fig. 6) raffigura un'ipotetica sequenza di operazioni per l'algoritmo responsabile della validazione. Per ogni vista del modello, la scala di rappresentazione è data

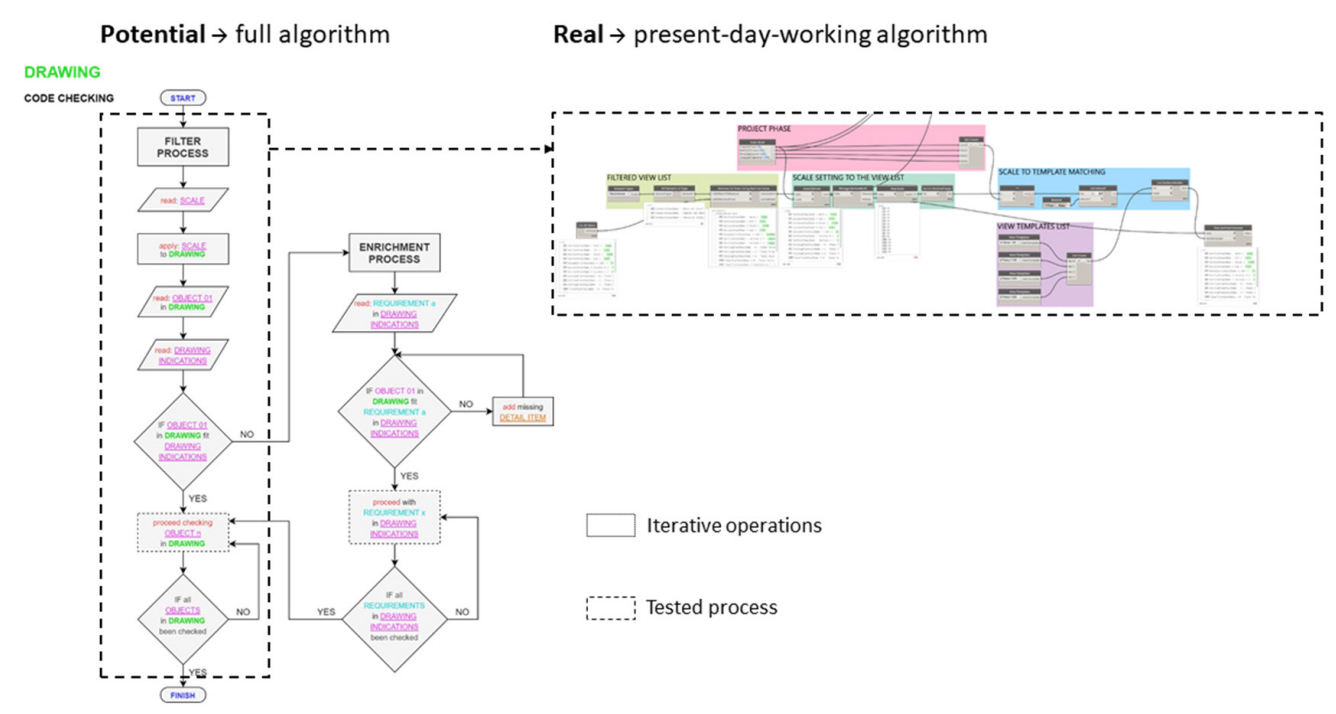


come primo input e immediatamente associata alla vista. Oggetto per oggetto, si verifica la rispondenza alle norme del disegno. Se la rappresentazione è corretta, l'algoritmo procede con l'oggetto successivo; in caso contrario, inizia il processo di verifica e arricchimento. Tale processo considera, per ciascun oggetto, i requisiti specifici e le richieste normative. Per ognuno di questi, in caso di non conformità alle norme, il passo successivo è l'implementazione dell'oggetto con gli elementi mancanti necessari. Dopodiché, l'algoritmo prosegue con il requisito successivo, fino al soddisfacimento di ciascuno. A procedura completata, l'oggetto è considerato conforme alle norme, e l'elaboratore procede a cascata con gli altri oggetti. Lo schema logico, che rappresenta gli e che devono essere seguiti dalla macchina, è stato tradotto come Linguaggio di Programmazione Visuale (VPL) eseguibile dalla piattaforma BIM authoring (fig. 6). Lo script visibile sulla destra è il prototipo testato di una sezione dell'algoritmo completo, che deve essere ancora implementato nella sua interezza.

\section{Risultati}

Attualmente, la produzione di modelli BIM connessi in grado di rappresentare le informazioni del progetto è un concetto migliorabile per ottenere un processo più efficiente sia per la rappresentazione dei dati che per il processo IPD. In particolare, per lo sviluppo di un archivio digitale ottimizzato in grado di raccogliere informazioni grafiche ed alfanumeriche si deve ancora considerare come input sia i requisiti informativi che le impostazioni grafiche. Questo contributo evidenzia la bontà dell'introdurre passaggi automatici nel processo edilizio per facilitare la produzione di disegni di progetto, stabilendo una connessione tra input e output attraverso l'uso di standard grafici. Perciò, il livello di automazione necessario per produrre corretti elaborati è stato valutato attraverso la visualizzazione grafica dello sforzo necessario (fig. 7), considerando la corrispondenza tra gli standard grafici e le impostazioni del software. Ad esempio, l'impostazione Detail Level permette di regolare la visibilità dei vari oggetti del modello in modo più semplice rispetto all'impostazione Cut profile che richiede uno sforzo maggiore, in quanto deve essere applicata a ogni oggetto.

Quindi, il processo automatico proposto presenta ancora alcune criticità, dovute sia ai limiti tecnologici attuali sia all'unicità di ogni progetto, per scelte tecniche e costruttive.

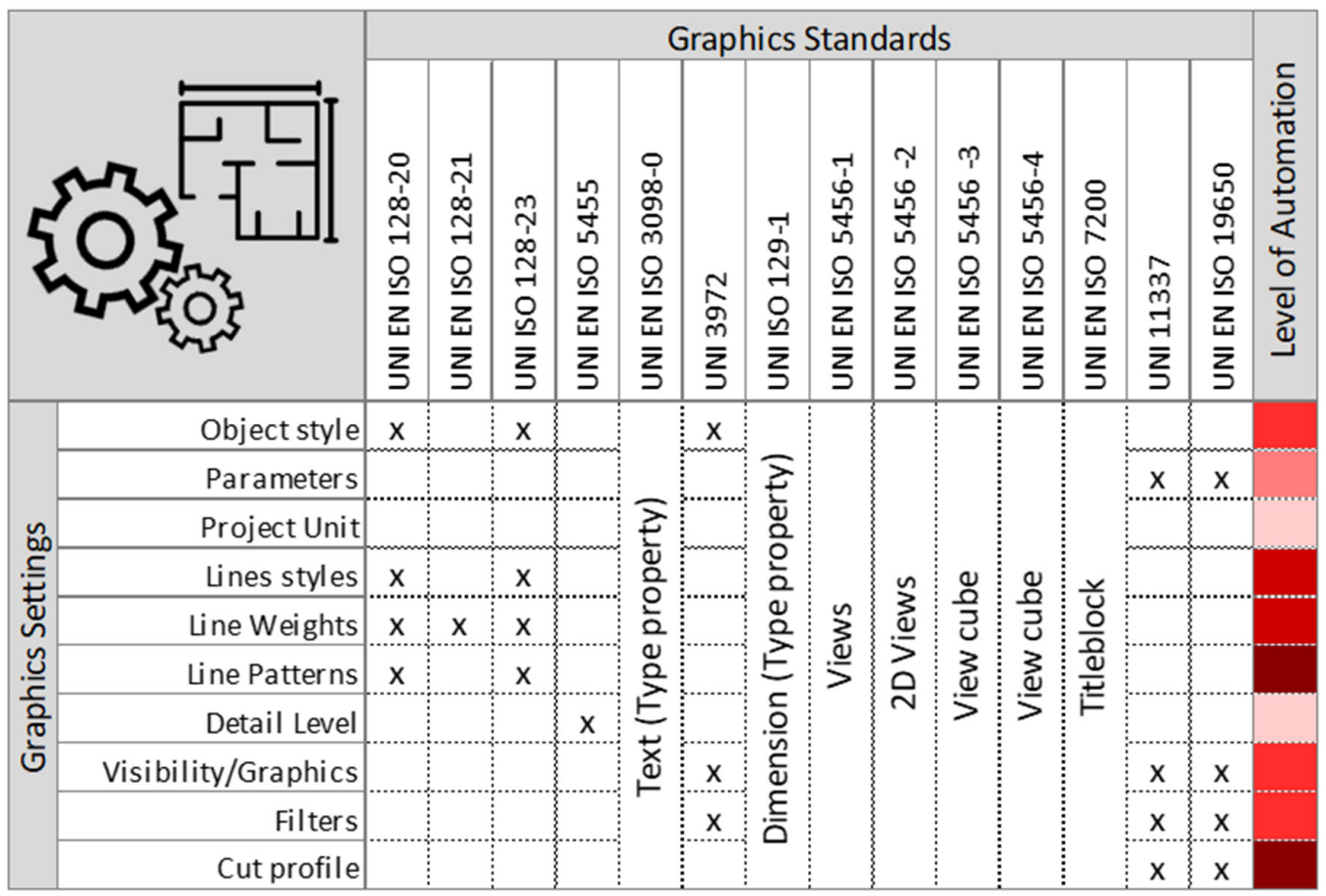


In pratica, è possibile agire sul processo di filtraggio, attraverso impostazioni che possono essere incorporate nei template di progetto modificate tramite script (es. script Dynamo), in base alla scala di rappresentazione impostata per specifiche viste. D'altra parte, la completa automazione della fase di arricchimento è ancora perfettibile, poiché molti elementi di questa fase del processo devono essere inseriti singolarmente. Di fatto, lo sviluppo di disegni dai modelli BIM implica anche la collocazione di altri tipi di oggetti, come i Detail Items e le Annotations, che determinano una migliore comunicazione del progetto.

Il contributo proposto fa risaltare che lo sforzo necessario per completare i diversi compiti che fanno parte del processo di rappresentazione è differente, a seconda della funzionalità selezionata, attivata o utilizzata in una particolare vista o gruppo di viste.

Questo contributo ha indagato anche la congruità delle scale LOD alle fasi di progettazione, cercando di stabilire una corrispondenza con le relative scale rappresentazione. Pertanto, il livello informativo prodotto nelle tavole di progetto deve essere considerato uno dei requisiti per la definizione dei level of information need definiti dalla ISO 19650.

\section{Conclusioni}

In quest'epoca della connessione, l'industria delle costruzioni è orientata verso l'adozione di un processo BIM basato sull'elaborazione di un modello parametrico che ottimizzi la comunicazione tra gli attori coinvolti. Attività come lo sviluppo di prodotti progettuali e l'aggiornamento informativo lungo tutto il ciclo di vita dell'edificio dovrebbero essere basate sullo sviluppo di un modello collegato a banche dati eterogenee per lo sviluppo di una smart city. Per questo motivo, l'automatizzazione del processo di creazione di documenti rispondenti ai requisiti normativi è stata analizzata in questo contributo per colmare il divario attuale tra semplice visualizzazione e corretta rappresentazione (fig. 8). Un ulteriore miglioramento potrebbe essere l'autoregolazione di tali algoritmi in risposta ai dati immessi. In futuro, la definizione dei requisiti dei documenti di progetto potrà essere ulteriormente codificata attraverso sistemi in grado di rielaborare le informazioni raccolte nei vari database, per trasferirle in rappresentazioni finalizzate della realtà.

Poiché attualmente la condivisione delle informazioni è molto complessa e limitata, auspicabilmente nel prossimo futuro l'innovazione tecnologica favorirà metodi e strumenti per realizzare un modello BIM connesso da utilizzare con diverse interfacce per le molteplici specificità della società.

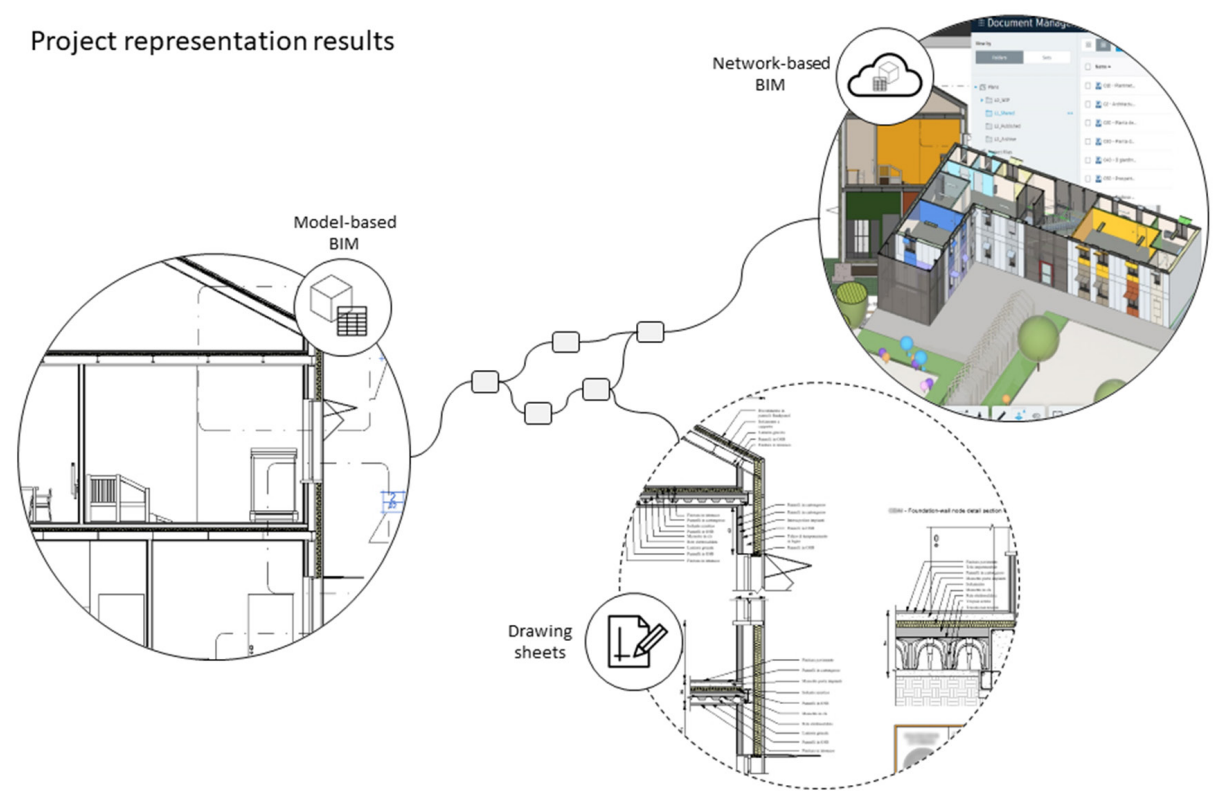




\section{Ringraziamenti}

Gli autori concordano sui contenuti, l'approccio metodologico e sulle considerazioni finali presentati in questa ricerca. In particolare, Matteo Del Giudice ha introdotto il contributo nel primo paragrafo sviluppando l'introduzione. La metodologia è stata affrontata sia da Matteo Del Giudice che da Emmanuele lacono. Quest'ultimo si è dedicato ai risultati ottenuti, mentre le conclusioni vogliono essere una sintesi dei due autori. Si ringrazia la tesista Isabella Dusi per aver acconsentito alla diffusione di alcuni contenuti sviluppati nella sua tesi di laurea

\section{Riferimenti bibliografici}

Autodesk (2020). BIM and the cloud for building design. Improved project insight with connected BIM. Autodesk.comhttps:// www.autodesk.com/solutions/bim/discover-building-design/bim-for-building-design. Retrieved Februray 19th, 2020.

De Gregorio Marco (2018). BIM: la normazione nel futuro dell'edilizia. In U\&C Dossier UNI, 8, pp. 19-34.

Caffi Vittorio et al. (2017). II BIM e gli standard di modellazione e rappresentazione. II processo edilizio supportato dal BIM: I'approccio INNOVance. Roma: Edilstampa.

Garzino Giorgio (20I I ). Disegno (e) in_formazione. Disegno politecnico. Segrate (MI): Politecnica, Maggioli Editore.

Mateev Michael (2020). Industry 4.0 and the digital twin for building industry. In International Scientific Journals of Scientific Technical Union of Mechanical Engineering "Industry 4.0", Issue I, vol. 5, pp. 29-32.

Novello Giuseppa, Lo Turco Massimiliano (20 I4). Linee guida per la modellazione dei componenti in ambiente BIM. Torino: Politecnico di Torino.

Osello Anna (20 I2). Il futuro del disegno con il BIM per Ingegneri e Architetti. Roma: Gangemi Editore.

Pavan Alberto, Mirarchi Claudio, Giani Matteo (2017). BIM: metodi e strumenti. Progettare, costruire e gestire nell'era digitale. Milano:Tecniche Nuove.

Ratti Carlo, Claudel Matthew (2017). La città di domani. Come le reti stanno cambiando il futuro urbano. Torino: Einaudi.

Succar Bilal (2009). Building Information Modelling Maturity Matrix. In Underwood Jason, Isikdag Umit. Handbook of Research on Building Information Modelling and Construction Informatics: Concepts and Technologies, pp. 65- I03. Information Science Reference, Gl Publishing.

Autori

Matteo Del Giudice, Politecnico di Torino, matteo.delgiudice@polito.it

Emmanuele lacono, Università del Piemonte, emmanuele.iacono@uniupo.it

Per citare questo capitolo: Del Giudice Matteo, lacono Emmanuele (2020). Approccio algoritmico per l'applicazione degli standard grafici in ambiente BIM/Algorithmic approach for the application of graphic standards in the BIM environment In Arena A Arena M. Brandolino R.G., ambiente BIM/Algorithmic approach for the application of graphic standards in the BIM environment. In Arena A., Arena M., Brandolino R.G., Colistra D., Ginex G., Mediati D., Nucifora S., Raffa P. (a cura di). Connettere. Un disegno per annodare e tessere. Atti del $42^{\circ}$ Convegno Internazionale
dei Docenti delle Discipline della Rappresentazione/Connecting. Drawing for weaving relationships. Proceedings of the 42 th International Conference of 


\title{
Algorithmic Approach for the Application of Graphic Standards in the BIM Environment
}

\author{
Matteo Del Giudice \\ Emmanuele lacono
}

Abstract

Technology and innovation are currently changing the building industry, influenced by the digitization process of the 4th industrial revolution.

Likewise, this growth affects the capability of data domains to enable connections between digital building information and representation collected over its entire lifecycle with several loT devices. One of the innovations is the development of digital repositories based on the Building Information Modeling (BIM) methodology, which allows information delivery using both traditional and innovative representation strategies, as this era of connection requires network-based models with high BIM maturity level.

Since the production of project material still relies on traditional drawing standards, the paper aims to assess the ability of collaborative BIM models to deliver 2D and 3D graphical production, according to the building process phases.

Considering the difference between views and drawings, the contribution provides an algorithm-based analytical approach capable of optimizing the BIM objects visualization, according to the scale of representation associated with their level of graphical and alphanumerical detail.

The challenges found by the present study are mainly issues concerning the limits of current technology and the contrast between object-based methodologies and sign-based standards, which force users to inefficiently manipulate smart BIM representations with manual additions.

Keywords

Building Information Modeling; Visual Programming Language; graphic standards; connected BIM; algorithms.

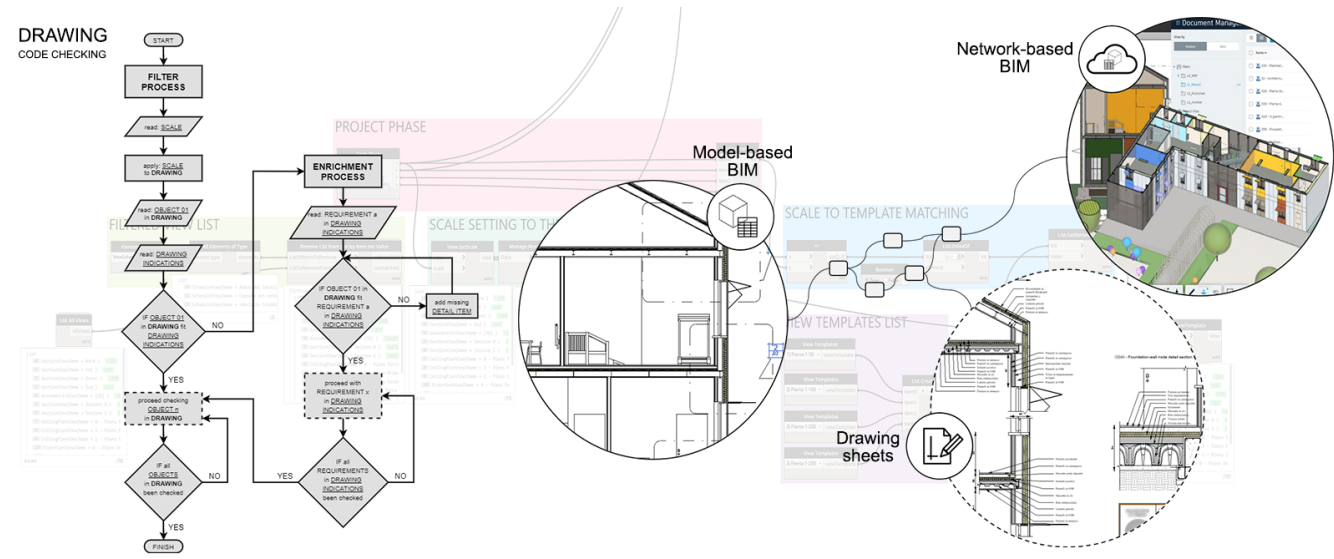




\section{Introduction}

In recent years, the construction sector has been going through a digitization process influenced by Information and Communication Technologies (ICTs) that are changing the way to communicate design ideas. Contemporary society, led by technology innovation, is moving towards increasingly complex and connected systems to optimize data management and develop smart cities and smart societies.

The introduction of building sensor networks allows developing innovative building models not only through its physical components, but also through its dynamic behavior. These models therefore need graphical interfaces that must be able to describe reality to fulfill the needs of the stakeholders involved.

For this reason, the design representation is heading towards the Building Information Modelling (BIM) methodology, based on the elaboration of a parametric 3D model, rich of graphical and alphanumerical contents, able to optimize the information management of the building process [Osello 20I2].

The informative models must then be organized in order to be represented not only through graphical standards and conventions but also in innovative ways such as Virtual and Augmented Reality (VAR). In this sense, the development of models able to represent physical buildings and their behavior involves the generation of a parametric 3D model linked to the various sensors that must be connected to each other for the generation of a digital twin [Mateev 2020].

In this era of connection [Autodesk 2020], the development of connected BIM models should be based on: I) datasets capable of describing static and dynamic building characteristics; 2) algorithms capable of processing large amounts of data to know the present and predict the future; 3 ) smart interfaces to facilitate human-machine interaction (fig. I). All of this should be possible by sharing information among users [Ratti et al. 20 I 7; Garzino 20 I I]. Currently, the concept of connected BIM model is often linked to the development of Common Data Environments (CDEs), which however, are not linked with algorithms capable of optimizing the graphical representation according to the design requirement, not reaching the proper BIM maturity level required for Integrated Project Delivery (IPD) [Underwood et al. 2009].

The reality is also that this type of connection means, at best, the possibility of using cloud-based systems for the sole visualization of these models. A best scenario would be one in which all the stakeholders could be able not only to just visualize but also to act directly on the work-in-progress model for what their respective field of work is concerned.

Although the current BIM process generates significantly improved design drawings as a result of an integrated scheme of models, analytical tools, Big Data, and collaborative in-

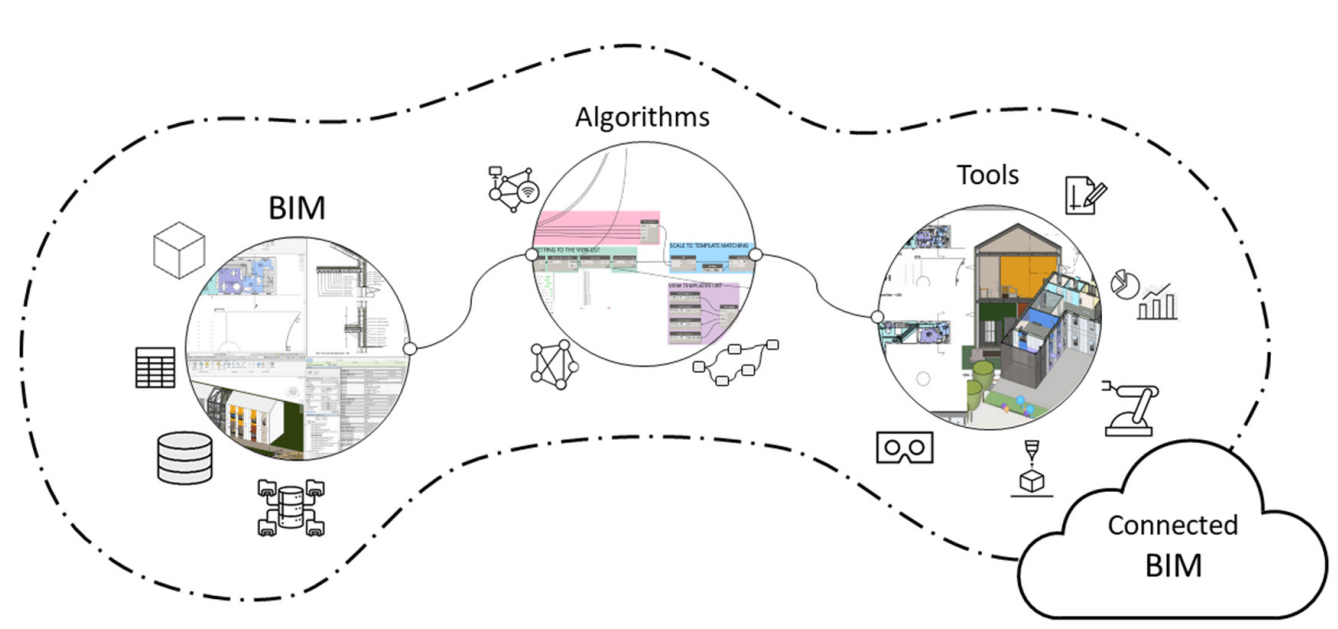


frastructures, there is currently a deviation between the production of these visualizations and the graphical representations that refer to standards and conventions encoded in the drawing discipline.

This paper presents an algorithm-based analytical approach aimed at optimizing the BIM-based graphical representation. The proposed approach involves the automatic application of the representation rules applied to BIM model views to bring the contents provided by the BIM platforms closer to those required by drawing regulation, of which the analysis has begun in the context of the drawing course held by prof. Novello at Politecnico di Torino.

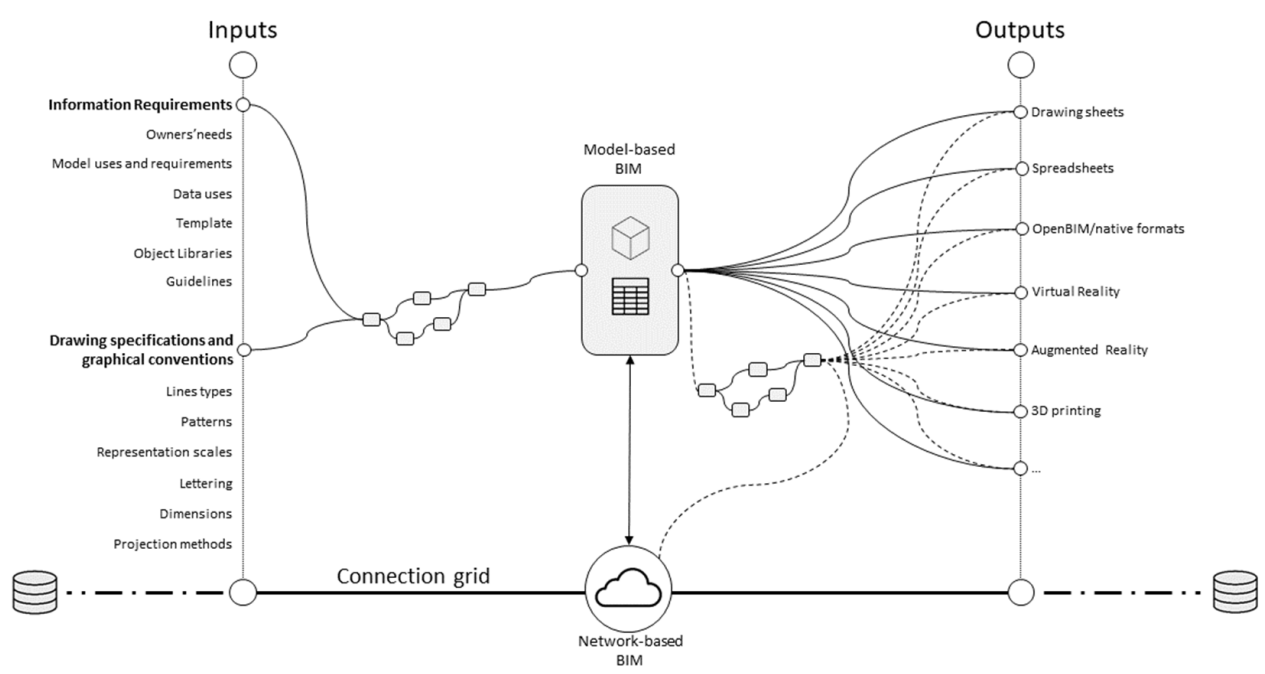

\section{Methodology}

Currently, the creation of a proper connected BIM model is based on three main steps: I) input definition; 2) 3D parametric file-based model creation; 3) outputs production. In particular, the development of a 3D parametric model starts from information requirements, drawing specifications and graphical conventions as an input. These have to be manipulated to achieve graphical and alphanumerical outputs able to improve the communication of the project.

The manipulation process is currently based on algorithms that are structured ad-hoc for these kinds of conversion operations, and which are regulated by the users allowed to set them for the specific project, requirements and outputs. This way, all the project representations are made compliant to the adopted standards without further manipulation, with a resulting benefit on the representation level.

At the present day, the achievement of a connected BIM model (fig. 2) implies its upload into a network-based platform to increase the level of information sharing. This kind of connection between the file-based model and the network model could be regulated by algorithms as well.

To unify the different modes of project representation, it is first of all fundamental to consider both those concerning the building process itself and those of the BIM methodology (fig. 3). Regarding the former, the Public Contracts Code (Legislative Decree 50/20/6), some macro-phases of the building process are indicated, in particular concerning the design phase. The phases before and after the design ones are added to complete the process sequence. On the BIM methodology side, however, there are Levels of Development (LOD), which the Italian legislation splits in seven bands, varying from one another in both graphical and informative contents [De Gregorio 2018] [Novello et al. 2014]. Moreover, there is the concept of Graphic Detail (GraDe), proposed by the AEC (UK) BIM Protocol 
V2.0, which however only concerns the graphic content of the models [Caffi et al. 20 I7]. By identifying a correspondence between these three different expressions of the project evolution, through the scales of representation, it is possible to trace a logical path that allows, starting from the design needs and requirements of the current phase of the process, to set automatically the correct representations and contents of such phase.

Once the phase, scale, LOD, as well as the project requirements are laid out, the proposed workflow (fig. 4) shows an algorithm made by a series of matrices able to set the project representation accordingly. Ideally, it goes as follows: depending on the moment of the project in which the user is, there is a corresponding phase of the building process, be it the feasibility study, the definitive design phase, or the executive design phase. This is a first input into the logical scheme. A second one is given by the LOD, according to the level of detail to be achieved in the various project elaborations, and the respective information content.

\begin{tabular}{|c|c|c|c|c|c|c|c|c|c|}
\hline \multirow[b]{2}{*}{ LOD } & \multicolumn{8}{|c|}{ Project phases } & \multirow[b]{2}{*}{ GRADE } \\
\hline & Survey & $\begin{array}{c}\text { Feasibility } \\
\text { study }\end{array}$ & $\begin{array}{c}\text { Preliminary } \\
\text { project }\end{array}$ & $\begin{array}{c}\text { Definitive } \\
\text { project }\end{array}$ & $\begin{array}{c}\text { Executive } \\
\text { project }\end{array}$ & Accounting & $\begin{array}{c}\text { Technical } \\
\text { testing }\end{array}$ & Life-cycle & \\
\hline A & & $1: \geq 500$ & $1: \geq 500$ & $1: 500$ & $1: 500$ & & & & 0 \\
\hline$B$ & $1: \geq 200$ & & $1: 200$ & & $\bullet$ & & & & 1 \\
\hline C & \multirow{5}{*}{\multicolumn{2}{|c|}{ 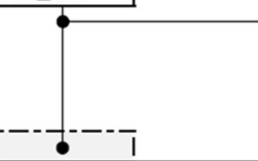 }} & & \multirow[t]{5}{*}{ 1:100 } & & & & $\because$ & \multirow{2}{*}{2} \\
\hline $\mathrm{D}$ & & & & & $1: 50$ & & & $\bullet$ & \\
\hline$E$ & & & & & $1: 20$ & $1: 20$ & & $\bullet$ & \multirow{3}{*}{3} \\
\hline $\mathrm{F}$ & & & & & $1: 5$ & $1: 5$ & $1: 5$ & $\bullet$ & \\
\hline G & & & & & $1: 1$ & $1: 1$ & $1: 1$ & $1: 1$ & \\
\hline
\end{tabular}

The possibility to cross the phase of the building process with the LOD, in particular with the graphic component related to the LOD, establishes what the correct representation scales are (i.e. 1:500, I:200, I: I 00 etc.) to fulfill the project requests. Immediately following this there is the correlation between the scale of representation and the products to be delivered in order to correctly communicate the project; the latter also constitutes the third and final input given to the algorithm. The project, divided into its required representations, crosses the scales required by the first two inputs, generating a first matrix of the documents necessary in order to complete the phase of the process in which the designer is working. More in detail, each element of this matrix must be passed through a so-called 'Filter', identified for each type of view (i.e. 1:200 plans, I: I00 sections, I:50 executive drawings, I:20 details etc.). The filter is a series of system requirements, for which there is one or more specific settings within the software used (line thicknesses, line types, hatches, profiles etc.). This operation should optimize the visualization of the various views of the model according to the conventions and regulations on drawing and representation. A second step concerns what has been identified with the term 'Enrichment', that being a specific implementation of the contents and views of the model. Each model object is evaluated with operations that add specific elements to those objects through categories of detail elements and detail lines,

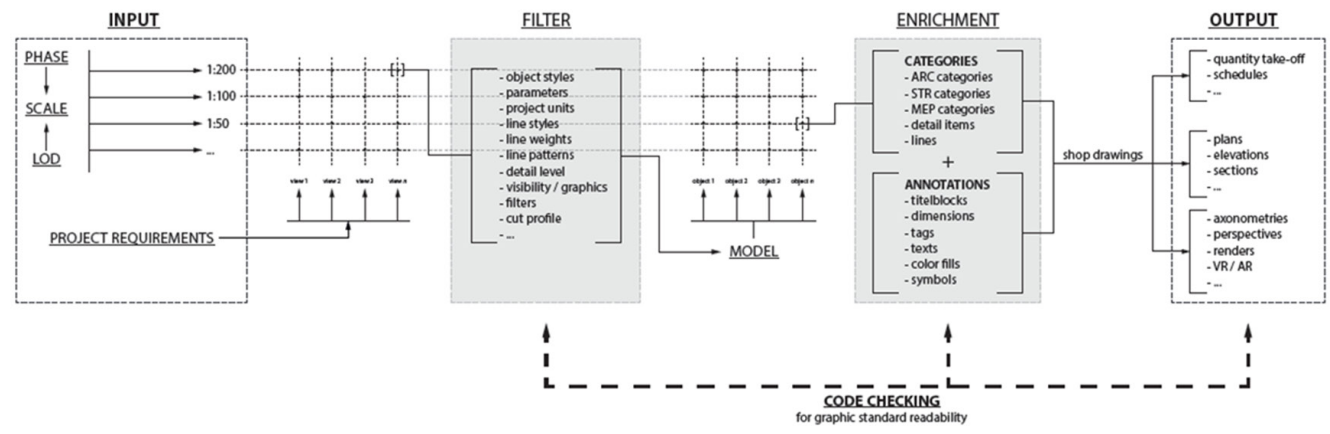


as well as operations that act on the views by adding annotation categories elements (i.e. title blocks, dimensions, symbols, tags or texts). Once the enrichment step is finished, shop drawings that actually meet the regulatory requirements can be produced, whether they are 2D (plans, elevations, sections, schedules etc.) or 3D representations (axonometric, perspective, render,VR/AR etc.). These establish the final output of the logical process, on which it is still possible to carry out a code checking, providing a feedback on the correctness of the filters set within the software.

The product of this set of complex operations is the improvement of the Level of Geometry (LOG) and the addition of various Detail Items helping to understand the more advan-

\section{OBJECTS LOD}
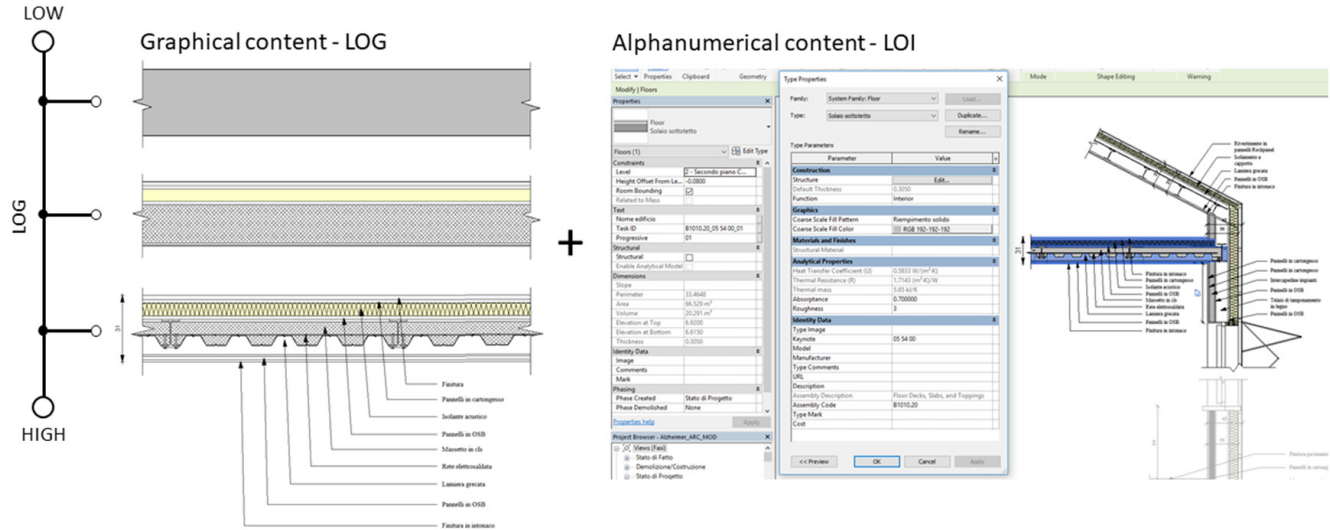

ced design stages, as well as the improvement of the Level of Information (LOI) [Pavan et al. 20 I7] (fig. 5). This operation involves, depending on the BIM authoring tools used, different sub-sets of representation settings, based on graphical filters, components addition, annotations, manual or automatic compilation of various object properties. For this study, Autodesk Revit was selected as the BIM authoring platform to evaluate strengths and weaknesses of the model. The level of automation is a crucial point in this process, since the less automation there is, the more effort-intensive the process becomes.

A flow chart (fig. 6) depicts a hypothetical operation sequence for the algorithm responsible for the code checking. For each view of the model, the drawing scale is initially given as

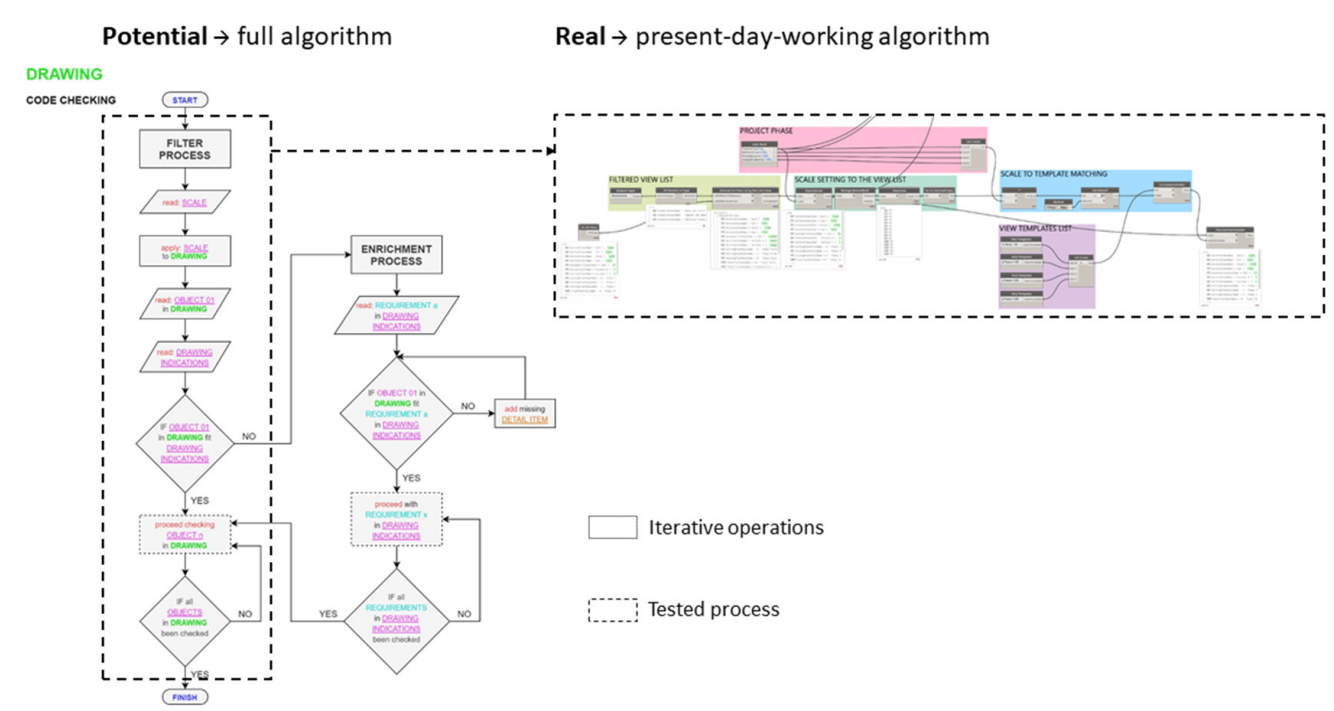


a first input and immediately associated to the view. Then, object by object, the standards compliance of its representation is verified. If the representation is correct, the algorithm proceeds with checking the next object; otherwise, the verification and enrichment process starts. This process considers, for the object to be verified, the individual requirements and regulatory requests. For each of these requirements, if there is not a correct compliance with the standards, then the next step is the implementation of the object with the missing elements necessary to satisfy the request. Subsequently, the algorithm goes on with the next requirement, until each of them is satisfied. Once the procedure is complete, the object is considered compliant with the standards, and the machine proceeds with the following object in the model.

The logical scheme, which represents the expression of the steps that have to be followed by the machine, was translated as Visual Programming Language (VPL) to be executed by the authoring BIM platform (fig. 6). In fact, the script visible on the right is the tested prototype of a section of the full algorithm, which still needs to be implemented in its entirety.

\section{Results}

Currently, the production of connected BIM models able to represent the project information is a concept that has to be improved in order to obtain a more efficient process both for data representation and for IPD. In particular, the development of an optimal model repository able to collect graphical and alphanumerical information still needs to consider as an input both information requirements and graphical settings.

This contribution underlines the goodness of introducing automatic steps to facilitate the production of project drawings establishing a connection between input and outputs through the use of graphical standards. An evaluation of the level of automation necessary to produce the proper outputs, considering the correspondence between graphical standards and the software settings, displays the amount of effort needed (fig. 7). For example, the Detail Level setting allows to regulate the visibility of various model objects more straightforwardly compared to the Cut profile setting, which needs more effort since it works as a one by one operation.

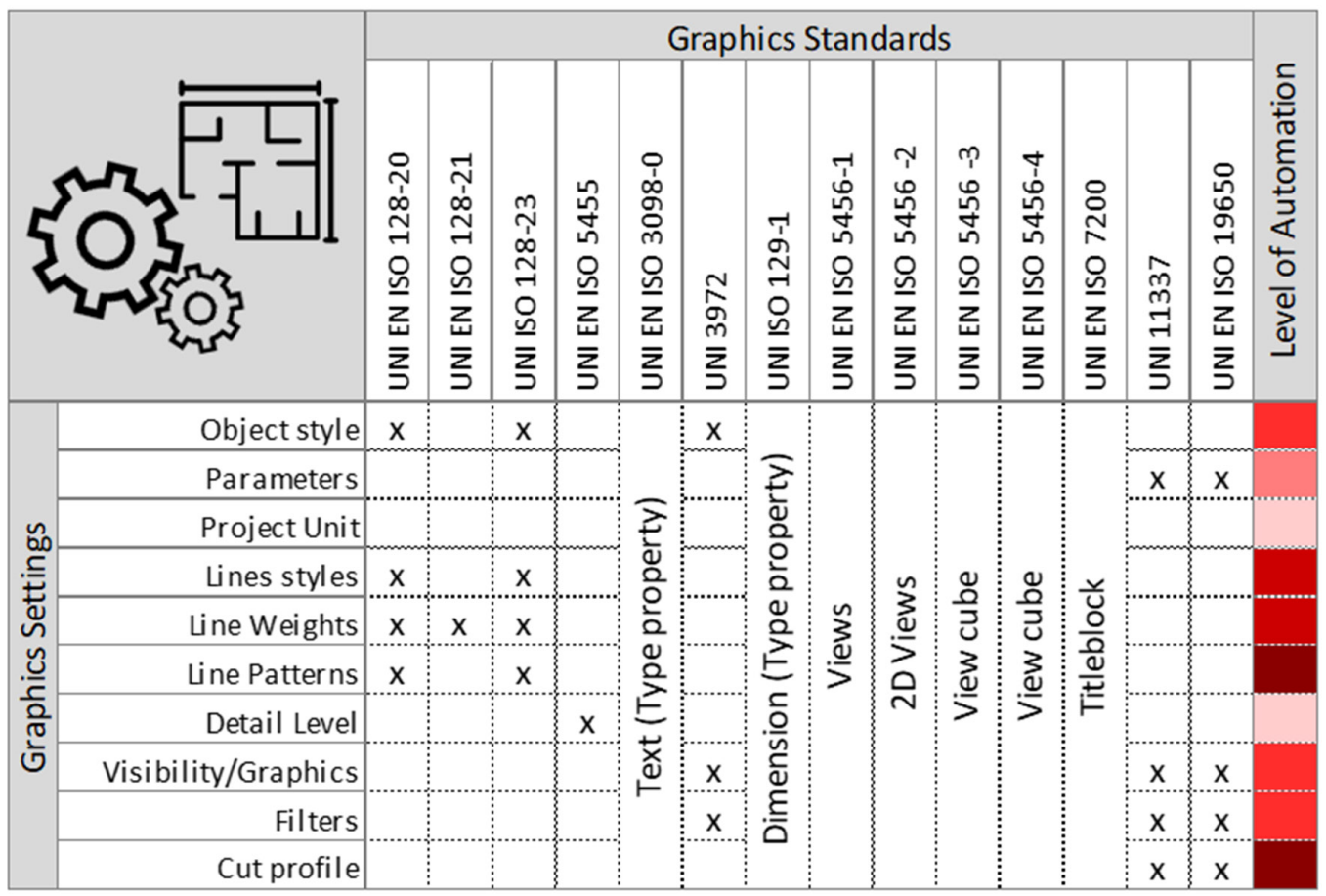


Moreover, this proposed automatic process still presents some flaws, due to both the limits of current technology and the uniqueness of some features of each project, in terms of technical and construction choices.

What can already be done is the filtering process, through settings that can be embedded in project templates interchanged through scripts (i.e. Dynamo scripts), based on the representation scale that is set to be in specific views. On the other hand, a full automation on the enrichment side is still to be perfected, since many elements of this process phase need to be singularly manipulated. Indeed, the development of drawings implies also the placement of other kinds of objects, such as Detail Items and Annotations, which provide a better project communication.

What emerges from this study is that the effort needed to complete the different tasks that are part of the representation process is different, depending on the feature that needs to be used, engaged, or added in a particular view or set of views.

This contribution investigated also the suitability of LOD ranges to the design phases, trying to establish a correspondence with the related view scales. Therefore, the information level produced in the design sheets has to be considered also one of the requirements for the level of information need definition defined by ISO 19650.

\section{Conclusions}

In this current age of connection, the building industry is oriented towards the adoption of a BIM process based on the elaboration of a parametric model which optimizes communication between the actors involved. Activities such as the production of project deliverables and the updating of information throughout the building life cycle should be based on the development of a model connected to heterogeneous datasets for the evolution of a smart city. The automation of the process of creating documents that meet the regulatory requirements has been analyzed in this contribution to bridge the gap between simple visualization and correct representation (fig. 8). A further improvement would be such algorithms being able to self-regulate in response to the given inputs. In the future, the definition of project documents requirements can be further codified through systems able to re-process the information contained in the various databases in order to transfer it into codified representations of reality.

Since information sharing is currently highly complex and limited, hopefully in the near future technological innovation will favor methods and tools for achieving a connected BIM model that can be used through different interfaces for the different specificities of society.

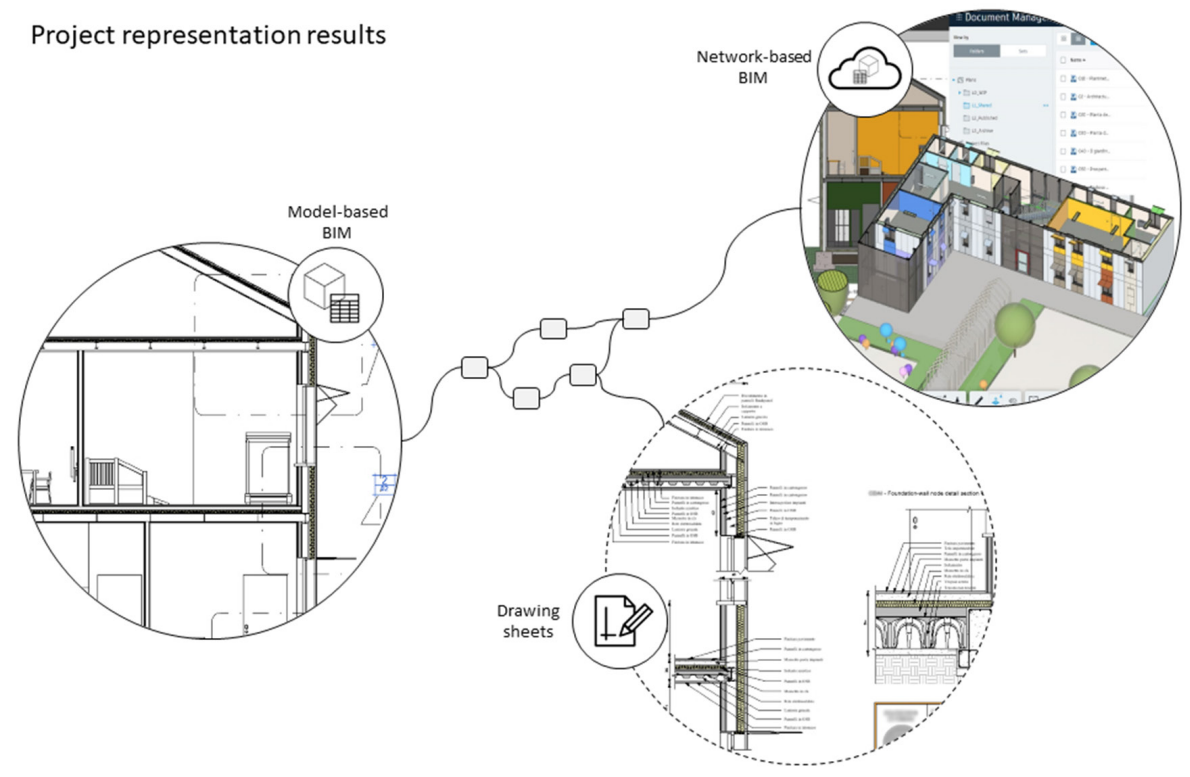




\section{Acknowledgements}

The authors agree on the contents, the methodological approach and on the final considerations presented in this research. In particular, Matteo Del Giudice introduced the contribution in the introduction paragraph. The methodology was investigated by both Matteo Del Giudice and Emmanuele lacono. Moreover, the latter explained the obtained results, while the conclusions are meant to be a synthesis of both the authors. The authors would like to thank the student Isabella Dusi for giving us the permission of diffusing a part of the content of her thesis.

\section{References}

Autodesk (2020). BIM and the cloud for building design. Improved project insight with connected BIM. Autodesk.comhttps:/ www.autodesk.com/solutions/bim/discover-building-design/bim-for-building-design. Retrieved Februray 19th, 2020.

De Gregorio Marco (20 8). BIM: la normazione nel futuro dell'edilizia. In U\&C Dossier UNI, 8, pp. 19-34.

Caffi Vittorio et al. (2017). II BIM e gli standard di modellazione e rappresentazione. II processo edilizio supportato dal BIM: I'approccio INNOVance. Roma: Edilstampa.

Garzino Giorgio (20 I I). Disegno (e) in_formazione. Disegno politecnico. Segrate (MI): Politecnica, Maggioli Editore.

Mateev Michael (2020). Industry 4.0 and the digital twin for building industry. In International Scientific Journals of Scientific Technical Union of Mechanical Engineering "Industry 4.0", Issue I, vol. 5, pp. 29-32.

Novello Giuseppa, Lo Turco Massimiliano (20 I4). Linee guida per la modellazione dei componenti in ambiente BIM. Torino: Politecnico di Torino.

Osello Anna (20 I2). Il futuro del disegno con il BIM per Ingegneri e Architetti. Roma: Gangemi Editore.

Pavan Alberto, Mirarchi Claudio, Giani Matteo (2017). BIM: metodi e strumenti. Progettare, costruire e gestire nell'era digitale. Milano:Tecniche Nuove.

Ratti Carlo, Claudel Matthew (2017). La città di domani. Come le reti stanno cambiando il futuro urbano. Torino: Einaudi.

Succar Bilal (2009). Building Information Modelling Maturity Matrix. In Underwood Jason, Isikdag Umit. Handbook of Research on Building Information Modelling and Construction Informatics: Concepts and Technologies, pp. 65- I03. Information Science Reference, IGI Publishing.

\section{Authors}

Matteo Del Giudice, Politecnico di Torino, matteo.delgiudice@polito.it

Emmanuele lacono, Università del Piemonte Orientale, emmanuele.iacono@uniupo.it

To cite this chapter: Del Giudice Matteo, lacono Emmanuele (2020). Approccio algoritmico per l'applicazione degli standard grafici in ambiente BIM/Algorithmic approach for the application of graphic standards in the BIM environment. In Arena A., Arena M., Brandolino R.G., Colistra D.,
Ginex G. Mediati D. Nucifora S. Raffa P. (a cura di). Connettere. Un disegno per annodare e tessere. Atti del $42^{\circ}$ Convegno Internazionale dei Docenti Ginex G., Mediati D., Nucifora S., Raffa P. (a cura di). Connettere. Un disegno per annodare e tessere. Atti del $42^{\circ}$ Convegno Internazionale dei Docenti
delle Discipline della Rappresentazione/Connecting. Drawing for weaving relationships. Proceedings of the 42 th International Conference of Representation Disciplines Teachers. Milano: FrancoAngeli, pp. 404-419. 